\title{
The impact of population-wide rapid antigen testing on SARS-CoV-2 prevalence in Slovakia
}

\begin{abstract}
Martin Pavelka, ${ }^{1,2,3 *}$, Kevin Van-Zandvoort ${ }^{4,5}$, Sam Abbott ${ }^{4,5}$, Katharine Sherratt $^{4,5}$, Marek Majdan $^{7}$, CMMID COVID-19 working group ${ }^{5}$, Inštitút Zdravotných Analýz ${ }^{2}$, Pavol Jarčuška ${ }^{7}$, Marek Krajčí1, Stefan Flasche ${ }^{4,5+}$, Sebastian Funk ${ }^{4,5}$ †

1Slovak Ministry of Health, Bratislava, Slovakia. 2Inštitút Zdravotných Analýz (Institute of Health Analyses), Bratislava, Slovakia. ${ }^{3}$ Department of Public Health and Policy, London School of Hygiene and Tropical Medicine, London, UK. ${ }^{4}$ Department for Infectious Disease Epidemiology, London School of Hygiene and Tropical Medicine, London, UK. ${ }^{5}$ Centre for Mathematical Modelling of Infectious Diseases, London School of Hygiene and Tropical Medicine, London, UK. ${ }^{6}$ Institute for Global Health and Epidemiology, Faculty of Health Sciences and Social Work, Trnava University, Trnava, Slovakia. PFaculty of Medicine, Pavol Jozef Šafárik University, Košice, Slovakia.
\end{abstract}

*Corresponding author. Email: martin.pavelka@health.gov.sk

†These authors contributed equally to this work.

Slovakia conducted multiple rounds of population-wide rapid antigen testing for SARS-CoV-2 in late 2020. combined with a period of additional contact restrictions. Observed prevalence decreased by $58 \%(95 \% \mathrm{Cl}$ : 57-58\%) within one week in the $\mathbf{4 5}$ counties that were subject to two rounds of mass testing, an estimate that remained robust when adjusting for multiple potential confounders. Adjusting for epidemic growth of 4.4\% (1.1-6.9\%) per day preceding the mass testing campaign, the estimated decrease in prevalence compared to a scenario of unmitigated growth was $70 \%$ (67-73\%). Modelling indicated that this decrease could not be explained solely by infection control measures, but required the additional impact of isolation and quarantine of household members of those testing positive.

Non-pharmaceutical interventions have been extensively used worldwide to limit the transmission of SARS-CoV-2 (1). These have included travel restrictions, mandating face masks, closure of schools and non-essential businesses, and nationwide stay-at-home orders. While all the measures were aimed at mitigating ill-health due to COVID-19 $(2,3)$ they also place an unprecedented economic and social burden on the majority of uninfected people $(4,5)$. Testing of reported symptomatic cases and tracing their contacts aims to provide a more targeted measure but, in many settings, has proven insufficient for containing transmission (6).

Mass testing campaigns are an alternative way to identify infectious individuals and allow targeting of interventions without much added burden to those not infectious. However, the Polymerase Chain Reaction (PCR) for the diagnosis of a SARS-CoV-2 infection is not suitable for mass use. While laboratory capacities have been upscaled in record time, PCR testing remains expensive and often has turnaround times of more than one day, diminishing its utility (7). The PCR detection window also typically extends to the post-infectious period by detecting RNA fragments, hence identifying as infected those who are no longer infectious (8).

By contrast rapid antigen tests are cheap and can be quickly produced in large quantities offering results on site in 15-30 min without the need for a laboratory. They are less sensitive in detecting infections with low viral load that are less likely to transmit, but can detect over $70 \%$ of likely infectious cases. A recent observational study estimated the sensitivity of lateral flow devices in detecting infectious individuals to be as high as $83-91 \%$ (9). This makes mass testing a viable part of the portfolio of non-pharmaceutical interventions $(10,11)$.

In October and November 2020, Slovakia used rapid antigen tests in a campaign targeting the whole population to identify infectious cases at scale, rapidly reduce transmission and thus allow easing of lockdown measures (12). A pilot took place between 23 and 25 October in the four most affected counties, followed by a round of national mass testing on 31 October and 1 November (henceforth: round 1). High prevalence counties were again targeted with a subsequent round of testing on 7 and 8 November (round 2).

In total, 5,276,832 SD-Biosensor Standard Q rapid antigen tests were conducted by trained medical personnel during the mass testing campaigns, with $65 \%$ of the respective populations tested in the pilot, $66 \%$ in mass testing Round 1 and $62 \%$ in Round 2 . This corresponded to $87 \%, 83 \%$ and $84 \%$ of the age-eligible population (i.e., 10 to 65 years and older adults in employment) in each round, respectively. It does not include residents who were quarantining at the time of the campaign and the 534,300 tests that were conducted on medical, military and governmental personnel who were not included in geographical county data.

A total of 50,466 participants tested positive, indicating the presence of currently infectious SARS-CoV-2. The 
proportion of positive tests was 3.91\% (range across counties: 3.12 to $4.84 \%$ ) in the pilot, $1.01 \%$ (range: $0.13-3.22 \%$ ) in Round 1 and $0.62 \%$ (range: $0.28-1.65 \%$ ) in Round 2 (Fig. 2, C and D).

The potential for large numbers of false positive tests has been a point of criticism for mass testing campaigns. While multiple studies have found high specificity for the Biosensor test kit they are not sufficiently powered to exclude specificity levels that at a population level would yield an overwhelming amount of false positives (13). From the low test-positive rates in some counties, we estimate that with $95 \%$ certainty the specificity of the SD Biosensor Standard Q antigen test exceeded $99.85 \%$ and the occurrence false positives was therefore not of major concern in this study.

The counties with the highest prevalence were found in the Northern part of the country, while the two main Slovakian cities of Bratislava and Košice had some of the lowest observed prevalences (Fig. 1C). Reflecting this pattern, we found high county-level prevalence was associated with a younger average population age and a lower population density (Figure S8). Given that prevalence varied at a much smaller than county scale (14), such associations may be clearer at the individual or community level, as observed in other countries.

In the four counties where the pilot was conducted, observed infection prevalence decreased by 56\% (95\% Confidence Interval, CI: 54-58\%) between the pilot and round 1 of the mass testing campaign and a further $60 \%$ (95\% CI: $56-$ $63 \%$ ) between rounds 1 and 2 , totaling a decrease of $82 \%$ (95\% CI: $81-83 \%)$ over two weeks. There was little heterogeneity between counties (Fig. 2B).

Among the 45 counties that were included in Round 2 of the mass testing campaign, observed infection prevalence decreased by $58 \%$ (95\% CI: $57-58 \%$ ) in one week. Combining the pilot results with the ones from the two rounds of testing in 45 counties, each round of mass testing was estimated to have reduced observed infection prevalence by $56 \%$ (95\% CI: $52-$ $59 \%$ ) when adjusted for attendance rates, reproduction number and prevalence in previous rounds. The estimated reduction between rounds varied considerably by county, from $29 \%$ in county Považská Bystrica to $79 \%$ in county Medzilaborce, but albeit hetrerogenous showed no regional pattern (Fig. 2A). Neither region, attendance rates, prevalence in Round 1 nor the estimated growth rate prior to mass testing showed any significant impact on the observed county-specific reductions.

At the time of Round 1 of the mass testing campaign, the incidence of confirmed cases reported through the syndromic surveillance system was rising in non-pilot counties with an estimated infection growth rate of $4.4 \%$ (1.1\%-6.9\%) per day. When adjusting for this growth trend, we estimated a selfadjusted prevalence ratio ( $\mathrm{saPR}$ ) of 0.30 (0.27-0.33). In the pilot counties, reported infection incidence showed signs of levelling in the week before the mass testing campaign with an estimated infection growth rate of $1.3 \%$ (-7.4-7.8\%), yielding a respective saPR of 0.31 (0.26-0.33).

As we used the test positivity rate of the subsequent round to estimate the impact of the previous one, we were unable to observe the impact of the last round in each county and hence the full effect of the campaign.

However, we found that the reduction achieved per round of testing was $56 \%$ (52-59\%), indicating that the 41 counties with two rounds of testing likely reduced infection prevalence by $81 \%$ (77-83\%) within two weeks and that the 4 counties included into the pilot testing reduced infection prevalence by 91\% (89-93\%) within three weeks.

The observational nature of this study made it difficult to separate the effects of the mass testing campaigns from that of the other non-pharmaceutical interventions introduced over the same period that aimed to reduce contacts and mobility, albeit much less than during the Spring lockdown (Figure S4). Nevertheless, a greater than 50\% decline in infection prevalence within one week (or $80 \%$ in two weeks) is striking, particularly while primary schools and workplaces were mostly open. For comparison, a month-long lockdown in November in the UK resulted in just a $30 \%$ decrease in prevalence (15). This, alongside the inability in December to control the rebounding spread of SARS-CoV-2 in Slovakia through even more stringent contact restrictions indicates the mass testing campaigns were responsible for a large share of case reduction in the previous months.

To further investigate the relationship between the reduction in prevalence, mass testing and non-pharmaceutical interventions, we used a microsimulation model for fine scale SARS-CoV-2 transmission in a representative county included in the pilot phase of the mass testing. Among the multiple intervention scenarios tested, only the scenario that assumed a substantial impact of both the additional contact reducing measures and the mass testing campaigns was able to generate reductions in test positivity rates between testing rounds that were similar to those observed (Fig. 3). Thus the requirement for quarantine for the whole household following a positive test was essential for the combined effect of mass testing and contact reduction measures. The model predicted a prevalence ratio between the first two testing rounds of $0.30(0.26-0.34)$ with household quarantine and $0.78(0.72-$ 0.84 ) without household quarantine.

Despite a reduction of more than $50 \%$ in test positivity between mass testing campaigns, standard syndromic surveillance did not report a rapid collapse in test-positive cases corresponding to drastic reductions in prevalence. This may be explained by a variety of reasons. Foremost, the national mass testing campaigns are likely to have a major disruptive effect on routine passive syndromic surveillance. Also, the ability of PCR to detect viral RNA well beyond the infectious 
period will partially mask a sudden drop in infectious cases. In addition, starting mid-September incidence surveillance has been operating at capacity with long waiting lists for testing and stricter eligibility criteria, which in the post mass testing period reduced substantially, and hence may have artificially reduced the observable change in these data. In contrast, data on hospital bed occupancy shows a sudden flattening from mid-November indicating a sharp decrease in new admissions consistent with a sizable reduction in new infections when the mass testing campaigns occurred (Figure S6).

Executing a large-scale mass testing campaign comes with several challenges. The need to mobilize sufficient medical personnel to conduct the nasopharyngeal swabs proved to be a major obstacle. Also, the logistics of mobilizing large numbers of assisting army personnel and vast amounts of testing and PPE material proved challenging. Some of the challenges could be overcome by using other rapid antigen tests with similarly high sensitivity but which are also licensed for use with nasal swabs $(16,17)$. Nasal swabs can be self-administered and reduce demand on trained personnel and transmission risk in the process of sample collection and can even enable testing at home. Self-administered swabs are also less intrusive and can be better suited for children and mass testing at schools. However, these benefits must be weighed against the potential loss of sensitivity if self-administered swabs are not conducted appropriately (18).The details of the Slovak mass testing experience need to be studied carefully before considering potential replication elsewhere (19).

In conclusion, the combination of nationwide restrictions and mass testing with quarantining of household contacts of test positives rapidly reduced the prevalence of infectious residents in Slovakia. While it was impossible to disentangle the precise contribution of control measures and mass testing, the latter is likely to have had a substantial effect in curbing the pandemic in Slovakia and may provide a valuable tool in future containment of SARS-CoV-2 elsewhere.

\section{REFERENCES AND NOTES}

1. Guidelines for the implementation of non-pharmaceutical interventions against COVID-19. Eur. Cent. Dis. Prev. Control (2020); https://www.ecdc.europa.eu/en/publications-data/covid-19-guidelines-nonpharmaceutical-interventions.

2. N. G. Davieset al., Lancet Public Health 0, (2020).10.1016/S2468-2667(20)30133$\mathrm{X}$

3. S. Flaxman, S. Mishra, A. Gandy, H. J. T. Unwin, T. A. Mellan, H. Coupland, C. Whittaker, H. Zhu, T. Berah, J. W. Eaton, M. Monod, A. C. Ghani, C. A. Donnelly, S. Riley, M. A. C. Vollmer, N. M. Ferguson, L. C. Okell, S. Bhatt; Imperial College COVID-19 Response Team, Estimating the effects of non-pharmaceutical interventions on COVID-19 in Europe. Nature 584, 257-261 (2020). doi:10.1038/s41586-020-2405-7 Medline

4. Everyone Included, Social Impact of COVID-19-Dros. Inf. Serv. D; https://www.un.org/development/desa/dspd/everyone-included-covid19.html.
5. Socio-economic impact of COVID-19. UNDP; https://www.undp.org/content/undp/en/home/coronavirus/socio-economicimpact-of-covid-19.html.

6. A. J. Kucharski, P. Klepac, A. J. K. Conlan, S. M. Kissler, M. L. Tang, H. Fry, J. R. Gog, W. J. Edmunds, J. C. Emery, G. Medley, J. D. Munday, T. W. Russell, Q. J. Leclerc, C. Diamond, S. R. Procter, A. Gimma, F. Y. Sun, H. P. Gibbs, A. Rosello, K. van Zandvoort, S. Hué, S. R. Meakin, A. K. Deol, G. Knight, T. Jombart, A. M. Foss, N. I. Bosse, K. E. Atkins, B. J. Quilty, R. Lowe, K. Prem, S. Flasche, C. A. B. Pearson, R. M. G. J. Houben, E. S. Nightingale, A. Endo, D. C. Tully, Y. Liu, J. Villabona-Arenas, K. O'Reilly, S. Funk, R. M. Eggo, M. Jit, E. M. Rees, J. Hellewell, S. Clifford, C. I. Jarvis, S. Abbott, M. Auzenbergs, N. G. Davies, D. Simons, CMMID COVID-19 working group, Effectiveness of isolation, testing, contact tracing, and physical distancing on reducing transmission of SARS-CoV-2 in different settings: A mathematical modelling study. Lancet Infect. Dis. 20, 1151-1160 (2020). doi:10.1016/S1473-3099(20)30457-6 Medline

7. M. E. Kretzschmar, G. Rozhnova, M. C. J. Bootsma, M. van Boven, J. H. H. M. van de Wijgert, M. J. M. Bonten, Impact of delays on effectiveness of contact tracing strategies for COVID-19: A modelling study. Lancet Public Health 5, e452-e459 (2020). doi:10.1016/S2468-2667(20)30157-2 Medline

8. R. Wölfel, V. M. Corman, W. Guggemos, M. Seilmaier, S. Zange, M. A. Müller, D. Niemeyer, T. C. Jones, P. Vollmar, C. Rothe, M. Hoelscher, T. Bleicker, S. Brünink, J. Schneider, R. Ehmann, K. Zwirglmaier, C. Drosten, C. Wendtner, Virological assessment of hospitalized patients with COVID-2019. Nature 581, 465-469 (2020). doi:10.1038/s41586-020-2196-x Medline

9. Oxford University, An observational study of SARS-CoV-2 infectivity by viral load and demographic factors and the utility lateral flow devices to prevent transmission; https://www.ox.ac.uk/news/2021-01-21-lateral-flow-devicesdetect-most-infectious-covid-19-cases-and-could-allow-safer.

10. M. J. Mina, R. Parker, D. B. Larremore, Rethinking Covid-19 Test Sensitivity - A Strategy for Containment. N. Engl. J. Med. 383, el20 (2020). 10.1056/NEJMp2025631 Medline

11. D. B. Larremore, B. Wilder, E. Lester, S. Shehata, J. M. Burke, J. A. Hay, M. Tambe, M. J. Mina, R. Parker, Test sensitivity is secondary to frequency and turnaround time for COVID-19 screening. Sci. Adv. 7, eabd5393 (2021). doi:10.1126/sciadv.abd5393 Medline

12. Som zodpovedný; https://www.somzodpovedny.sk.

13. Z. Iglòi et al., medRxiv 20234104 [Preprint] 20 November 2020. doi:10.1101/2020.11.18.20234104.

14. K. Bodová, R. Kollár, medRxiv 20248808 [Preprint] 26 December 2020 doi:10.1101/2020.12.23.20248808.

15. S. Riley et al., medRxiv 20239806 [Preprint] 2 December 2020. doi:10.1101/2020.11.30.20239806.

16. Panbio COVID-19 Ag Rapid Test Device, (available at https://www.globalpointofcare.abbott/en/product-details/panbio-covid-19-agantigen-test.html).

17. Sofia SARS Antigen FIA, Quidel; https://www.quidel.com/immunoassays/rapidsars-tests/sofia-sars-antigen-fia.

18. E. Mahase, BMJ 371, (2020). 10.1136/bmi.m4469

19. K. Landokova, How Slovakia tested 3.6 million people for COVID-19 in a single weekend; https://www.bi.team/blogs/how-slovakia-tested-3-6-million-peoplefor-covid-19-in-a-single-weekend.

20. Koronavírus a Slovensko; https://korona.gov.sk.

21. R Core Team, R: A Language and Environment for Statistical Computing (R Foundation for Statistical Computing, Vienna, Austria, 2019; https://www.Rproject.org/).

22. M. Pavelka et al., Data and R code accompanying the manuscript "The impact of population-wide rapid antigen testing on SARS-CoV-2 prevalence in Slovakia". Zenodo (2021); doi:10.5281/zenodo.4570939.

23. Products - STANDARD Q COVID-19 Ag: http://sdbiosensor.com/xe/product/7672.

24. A. Berger et al., medRxiv 20235341 [Preprint] 23 November 2020. doi:10.1101/2020.11.20.20235341.

25. J. L. Prince-Guerra, O. Almendares, L. D. Nolen, J. K. L. Gunn, A. P. Dale, S. A. Buono, M. Deutsch-Feldman, S. Suppiah, L. Hao, Y. Zeng, V. A. Stevens, K. Knipe, J. Pompey, C. Atherstone, D. P. Bui, T. Powell, A. Tamin, J. L. Harcourt, P. L. 
Shewmaker, M. Medrzycki, P. Wong, S. Jain, A. Tejada-Strop, S. Rogers, B. Emery, H. Wang, M. Petway, C. Bohannon, J. M. Folster, A. MacNeil, R. Salerno, W. Kuhnert-Tallman, J. E. Tate, N. J. Thornburg, H. L. Kirking, K. Sheiban, J. Kudrna, T. Cullen, K. K. Komatsu, J. M. Villanueva, D. A. Rose, J. C. Neatherlin, M. Anderson, P. A. Rota, M. A. Honein, W. A. Bower, Evaluation of Abbott BinaxNOW Rapid Antigen Test for SARS-CoV-2 Infection at Two Community-Based Testing SitesPima County, Arizona, November 3-17, 2020. MMWR Morb. Mortal. Wkly. Rep. 70 100-105 (2021). doi:10.15585/mmwr.mm7003e3 Medline

26. S. Abbott, J. Hellewell, R. N. Thompson, K. Sherratt, H. P. Gibbs, N. I. Bosse, J. D. Munday, S. Meakin, E. L. Doughty, J. Y. Chun, Y.-W. D. Chan, F. Finger, P. Campbell, A. Endo, C. A. B. Pearson, A. Gimma, T. Russell, S. Flasche, A. J. Kucharski, R. M. Eggo, S. Funk, Estimating the time-varying reproduction number of SARS-CoV-2 using national and subnational case counts. Wellcome Open Res. 5, 112 (2020). doi:10.12688/wellcomeopenres.16006.2

27. Statistics,

Eurostat; https://ec.europa.eu/eurostat/databrowser/view/cens_01rhsize/default/table ?lang=en.

28. K. Prem, A. R. Cook, M. Jit, Projecting social contact matrices in 152 countries using contact surveys and demographic data. PLOS Comput. Biol. 13, e1005697 (2017). doi:10.1371/journal.pcbi.1005697 Medline

29. United Nations, World Population prospects; https://www.google.com/url?q=https://population.un.org/wpp/Download/File s/1_Indicators\%2520(Standard)/EXCEL_FILES/1_Population/WPP2019_POP_F 01_1_TOTAL_POPULATION_BOTH_SEXES.xIsx\&sa=D\&source=editors\&ust=161 4209701533000\&usg=AOvVaw0e_BV1Z-ofSu_U005NeZBf.

30. European Commission, Eurostat Data Browser; https://ec.europa.eu/eurostat/databrowser/view/CENS_01RHSIZE_custom_ 214489/default/table?lang=en.

31. S. A. Lauer et al., Ann. Intern. Med. 10.7326/M20-0504 (2020).

32. L. Ferretti et al., medRxiv 20188516 [Preprint] 16 September 2020. doi:10.1101/2020.09.04.20188516 (2020)

33. Q. Bi, Y. Wu, S. Mei, C. Ye, X. Zou, Z. Zhang, X. Liu, L. Wei, S. A. Truelove, T. Zhang, W. Gao, C. Cheng, X. Tang, X. Wu, Y. Wu, B. Sun, S. Huang, Y. Sun, J. Zhang, T. Ma, J. Lessler, T. Feng, Epidemiology and transmission of COVID-19 in 391 cases and 1286 of their close contacts in Shenzhen, China: A retrospective cohort study. Lancet Infect. Dis. 20, 911-919 (2020). doi:10.1016/S1473-3099(20)30287-5 Medline

34. H. Nishiura, N. M. Linton, A. R. Akhmetzhanov, Serial interval of novel coronavirus (COVID-19) infections. Int. J. Infect. Dis. 93, 284-286 (2020). doi:10.1016/i.iiid.2020.02.060 Medline

35. Q. Li, X. Guan, P. Wu, X. Wang, L. Zhou, Y. Tong, R. Ren, K. S. M. Leung, E. H. Y. Lau, J. Y. Wong, X. Xing, N. Xiang, Y. Wu, C. Li, Q. Chen, D. Li, T. Liu, J. Zhao, M. Liu, W. Tu, C. Chen, L. Jin, R. Yang, Q. Wang, S. Zhou, R. Wang, H. Liu, Y. Luo, Y. Liu, G. Shao, H. Li, Z. Tao, Y. Yang, Z. Deng, B. Liu, Z. Ma, Y. Zhang, G. Shi, T. T. Y. Lam, J. T. Wu, G. F. Gao, B. J. Cowling, B. Yang, G. M. Leung, Z. Feng, Early Transmission Dynamics in Wuhan, China, of Novel Coronavirus-Infected Pneumonia. N. Engl. J. Med. 382, 1199-1207 (2020). doi:10.1056/NEJMoa2001316 Medline

36. N. G. Davies, P. Klepac, Y. Liu, K. Prem, M. Jit, R. M. Eggo; CMMID COVID-19 working group, Age-dependent effects in the transmission and control of COVID19 epidemics. Nat. Med. 26, 1205-1211 (2020). doi:10.1038/s41591-020-0962-9 Medline

37. Y. Liu, S. Funk, S. Flasche; Centre for Mathematical Modelling of Infectious Diseases $n \mathrm{C} \mathrm{V}$ V Working Group, The contribution of pre-symptomatic infection to the transmission dynamics of COVID-2019. Wellcome Open Res. 5, 58 (2020). doi:10.12688/wellcomeopenres.15788.1 Medline

38. X. He, E. H. Y. Lau, P. Wu, X. Deng, J. Wang, X. Hao, Y. C. Lau, J. Y. Wong, Y. Guan, X. Tan, X. Mo, Y. Chen, B. Liao, W. Chen, F. Hu, O. Zhang, M. Zhong, Y. Wu, L. Zhao, F. Zhang, B. J. Cowling, F. Li, G. M. Leung, Temporal dynamics in viral shedding and transmissibility of COVID-19. Nat. Med. 26, 672-675 (2020). doi:10.1038/s41591-020-0869-5 Medline

39. L. J. Krüger et al., medRxiv 20203836 [Preprint] 4 October 2020. doi:10.1101/2020.10.01.20203836 (2020)

\section{ACKNOWLEDGMENTS}

We would like to thank all healthcare workers, Slovak armed forces and countless volunteers who helped with the execution of the mass testing campaign. Further, we would like to thank all participants who contributed their time to help curb the pandemic and particularly those who had to quarantine as a result of their or their household's or contact's test result. The following authors were part of the Centre for Mathematical Modelling of Infectious Disease COVID-19 Working Group. Each contributed in processing, cleaning and interpretation of data, interpreted findings, contributed to the manuscript, and approved the work for publication: Gwenan M Knight, Naomi R Waterlow, Carl A B Pearson, Fiona Yueqian Sun, Simon R Procter, Alicia Showering, Rosalind M Eggo, Yung-Wai Desmond Chan, Emily S Nightingale, David Simons, Oliver Brady, Billy J Quilty, Petra Klepac, Amy Gimma, Hamish P Gibbs, W John Edmunds, Adam J Kucharski, Sam Abbott, Jack Williams, Kiesha Prem, Rosanna C Barnard, Thibaut Jombart, Graham Medley, Katherine E. Atkins, Samuel Clifford, Nicholas G. Davies, Kaja Abbas, Mark Jit, Timothy W Russell, Frank G Sandmann, Damien C Tully, James D Munday, Anna M Foss, Alicia Rosello, Sophie R Meakin, Joel Hellewell, C Julian Villabona-Arenas, Christopher I Jarvis, Rachel Lowe, Akira Endo, Matthew Quaife, Nikos I Bosse, Yang Liu. The following authors were part of the Inštitút Zdravotných Analýz. Each contributed in processing, cleaning and interpretation of data, interpreted findings, contributed to the manuscript, and approved the work for publication: Matej Mišík, Kristián Šufliarsky, Andrej Kluka, Eduard Kofira, Patrik Židuliak, Soňa Slobodníková, Jakub Červený. Funding: Sir Henry Dale Fellowship jointly funded by the Wellcome Trust and the Royal Society 208812/Z/17/Z (SF); Wellcome Trust Senior Research Fellowship (SF, $\mathrm{SA}, \mathrm{KS}$ ); Elrha's Research for Health in Humanitarian Crises (R2HC) Programme funded by the UK Government (DFID), the Wellcome Trust, and the UK National Institute for Health Research (NIHR) (KvZ). The following funding sources are acknowledged as providing funding for the working group authors: BBSRC LIDP BB/M009513/1 (DS); Bill \& Melinda Gates Foundation INV-001754 (MQ); INV003174 (KP, MJ, YL); OPP1157270 (KA); NTD Modelling Consortium OPP1184344 (CABP, GFM); OPP1180644 (SRP); OPP1183986 (ESN); DFID/Wellcome Trust Epidemic Preparedness Coronavirus research program 221303/Z/20/Z: (CABP); EDCTP2 RIA2020EF-2983-CSIGN (HPG); ERC \#757699 (MQ); The European Union's Horizon 2020 research and innovation program - project EpiPose 101003688 (KP, MJ, PK, RCB, WJE, YL); The Global Challenges Research Fund (GCRF) project 'RECAP' managed through RCUK and ESRC ES/P010873/1 (AG, CIJ, TJ); HDR UK MR/S003975/1 (RME); MRC MR/N013638/1 (NRW); Nakajima Foundation (AE); The National Institute for Health Research NIHR 16/136/46 (BJQ); 16/137/109 (BJQ, FYS, MJ, YL); Health Protection Research Unit for Immunisation NIHR200929 (NGD); Health Protection Research Unit for Modelling Methodology HPRU-2012-10096 (TJ); NIHR200908 (RME); NIHR200929 (FGS, MJ); PR-OD-1017-20002 (AR, WJE); The Royal Society Dorothy Hodgkin Fellowship (RL); RP\EA 180004 (PK); UK DHSC/UK Aid/NIHR PR-OD-1017-20001 (HPG); UK MRC MC_PC_19065-Covid 19: Understanding the dynamics and drivers of the COVID-19 epidemic using real-time outbreak analytics (AG, NGD, RME, SC, TJ, WJE, YL); MR/P014658/1 (GMK); The UK Public Health Rapid Support Team funded by the United Kingdom Department of Health and Social Care (TJ); Wellcome Trust 206250/Z/17/Z (AJK, TWR); 206471/Z/17/Z (OJB); 208812/Z/17/Z (SC); 210758/Z/18/Z (JDM, JH, NIB, SA, SRM). Author contributions: Conceptualization: MP, MM, PJ, MK, SeF, StF. Methodology: KvZ, SA,MM, SeF, StF. Software: KvZ, MM, SeF, StF. Validation: KvZ, SA, KS, PJ, MK, SeF, StF. Formal Analysis: MP, KvZ, SA, KS, MM, SeF, StF. Investigation: MP, KvZ, PJ, SeF, StF. Resources: MP, PJ, MK. Data Curation: MP, KvZ, PJ, MK, SeF, StF. Writing original draft: MP, KvZ, StF. Writing - review and editing: MP, KS, MM, PJ, MK, SeF, StF. Visualization: MP, KvZ, SeF, StF. Supervision: PJ, MK, SeF, StF. Project administration: MP, SeF, StF. Funding acquisition: Table 1: MP, SeF; Fig. 1: MP, KvZ, SeF, StF; Fig. 2: MP, KvZ, SeF, StF; Fig. 3: MP, KvZ, SeF, StF; Table S1: MP, KvZ, SeF, StF; Figure S1: SeF; Figure S2: KvZ; Figure S3: KvZ; Figure S4: SeF; Figure S5: KvZ; Figure S6: MP, SeF, StF; Figure S7: MP, SeF, StF; Figure S8: MP, SeF, StF; Table S2: SeF, StF; Table S3: MP, SeF, StF. Competing interests: Martin Pavelka is employed as epidemiologist and public health data analyst at the Slovak Ministry of Health but had no involvement in the design of the mass testing campaigns. Marek Krajčí is the current Slovak Minister of Health and was 
involved in the design of the mass testing campaigns. Sebastian Funk advises the UK government as a member of the Scientific Pandemic Influenza Group on Modelling (SPI-M) in an unpaid role. All other authors declare that they have no conflicts of interest. Data and materials availability: Daily incidence of positive COVID-19 test reports and the results of the mass testing are available through governmental websites $(12,20)$. All analyses were conducted in R $(21)$ and can be found at http://doi.org/10.5281/zenodo.4570939 and (22). This work is licensed under a Creative Commons Attribution 4.0 International (CC BY 4.0) license, which permits unrestricted use, distribution, and reproduction in any medium, provided the original work is properly cited. To view a copy of this license, visit https://creativecommons.org/licenses/by/4.0/. This license does not apply to figures/photos/artwork or other content included in the article that is credited to a third party; obtain authorization from the rights holder before using such material.

\section{SUPPLEMENTARY MATERIALS}

science.sciencemag.org/cgi/content/full/science.abf9648/DC1

Materials and Methods

Supplementary Text

Figs. S1 to $S 8$

Tables S1 to S3

References (23-39)

MDAR Reproducibility Checklist

1 December 2020; resubmitted 29 January 2021

Accepted 17 March 2021

Published online 23 March 2021

10.1126/science.abf9648 


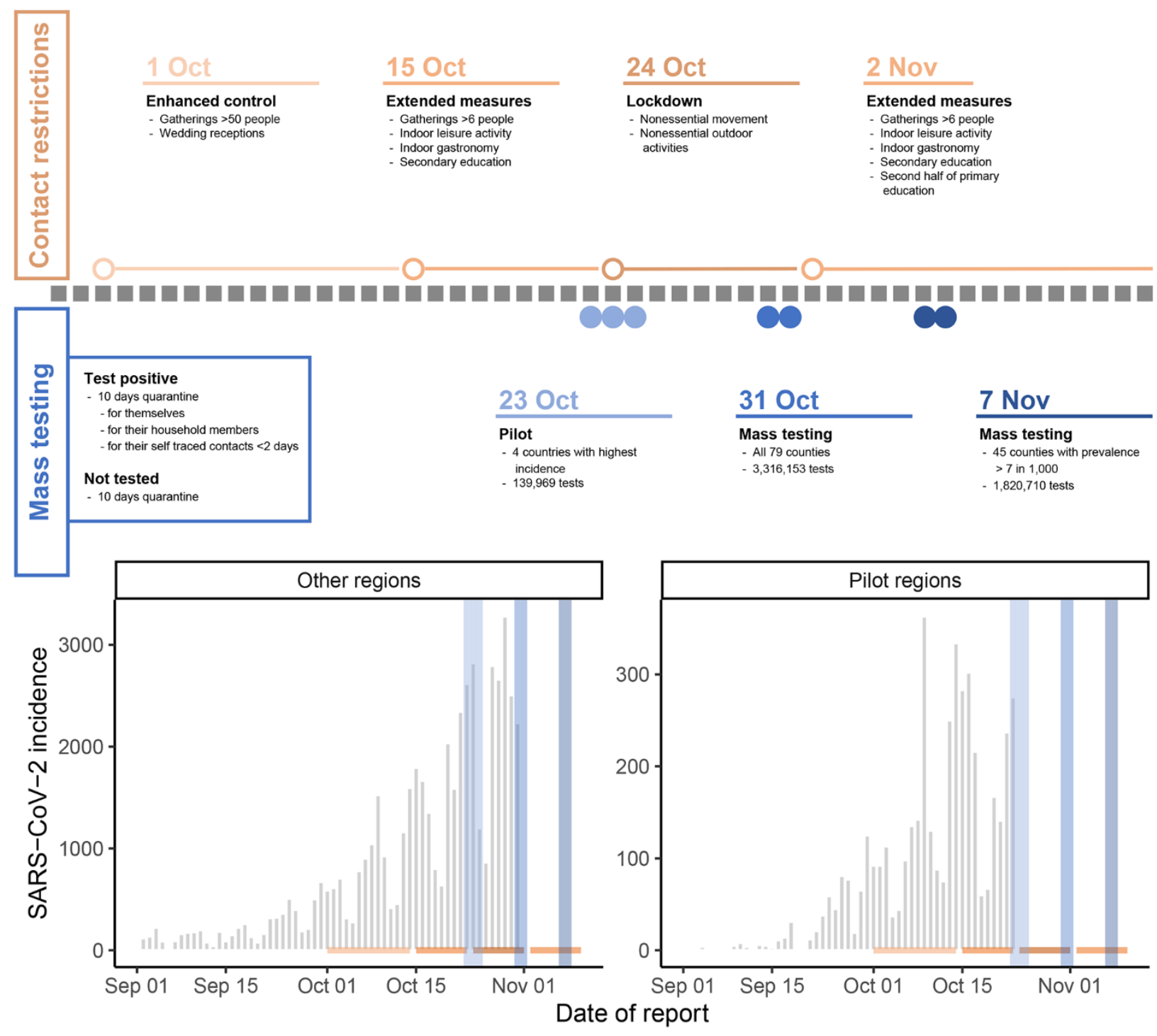

Fig. 1. Overview of interventions and pre mass testing epidemiology. (Top) Description of timing and extent of national contact restriction in Slovakia (color intensity indicates intensity of the measures) and timing and extent of the mass testing campaigns. Dots and lines in respective colors show the start and duration of the contact restrictions and the blue dots show the days on which mass testing was conducted, although the highest turnout was usually on the first day. (Left) Box illustrating contact reducing measures for those testingpositive and those who chose not to be tested. (Bottom) SARS-CoV-2 infection incidence as reported by the Slovak Ministry of Health and collected through passive symptom triggered PCR testing. Using the same color coding as in the top panel contact interventions are displayed by horizontal and mass testing campaigns by vertical lines. Data from the passive surveillance subsequent to the respective first mass testing campaign is omitted to clearly illustrate the trends in infection rates leading up to the mass testing and because mass testing is likely to have changed the sensitivity of the passive surveillance and thereby distorted the observation of infection trends following it. 
A

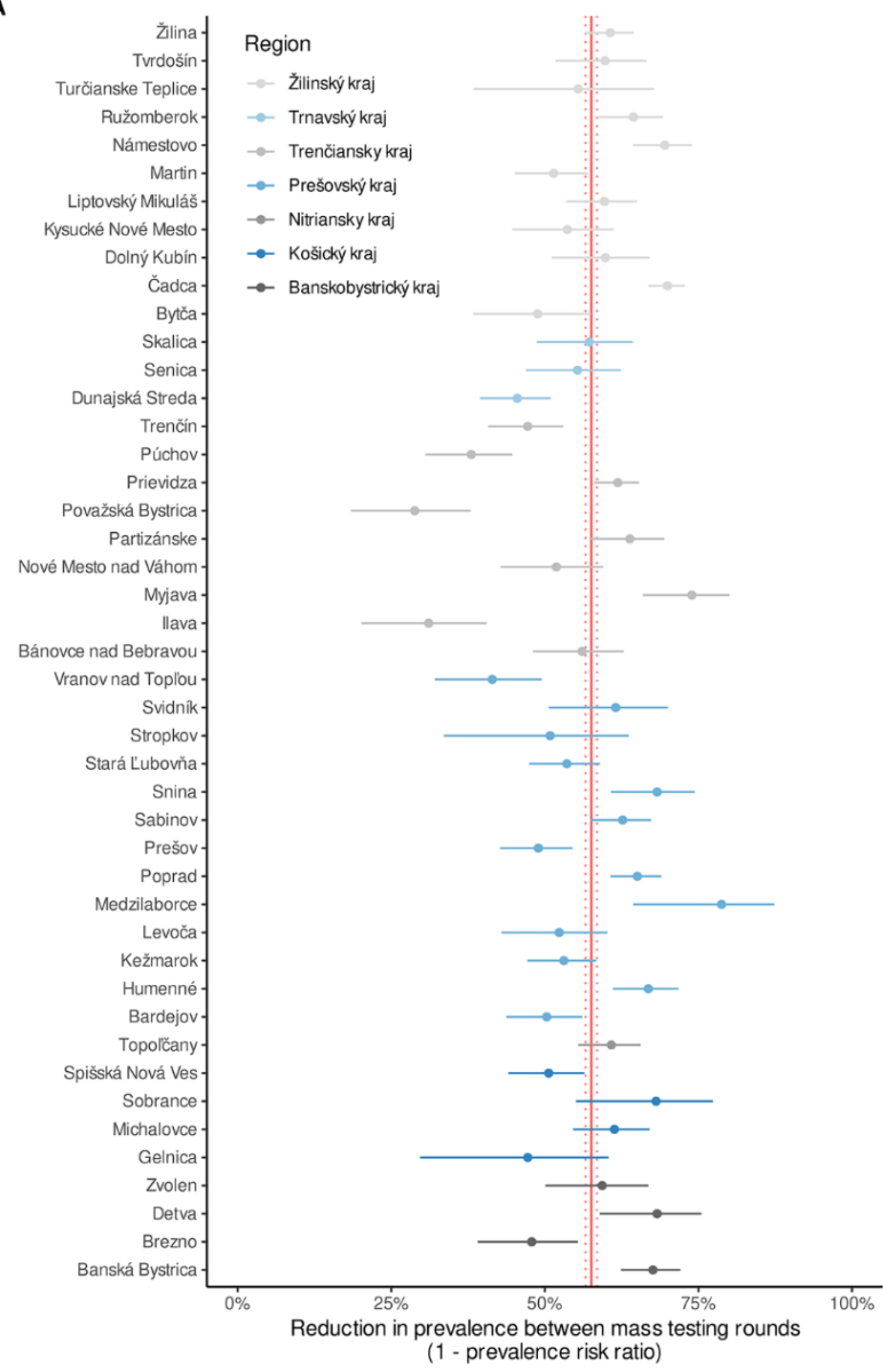

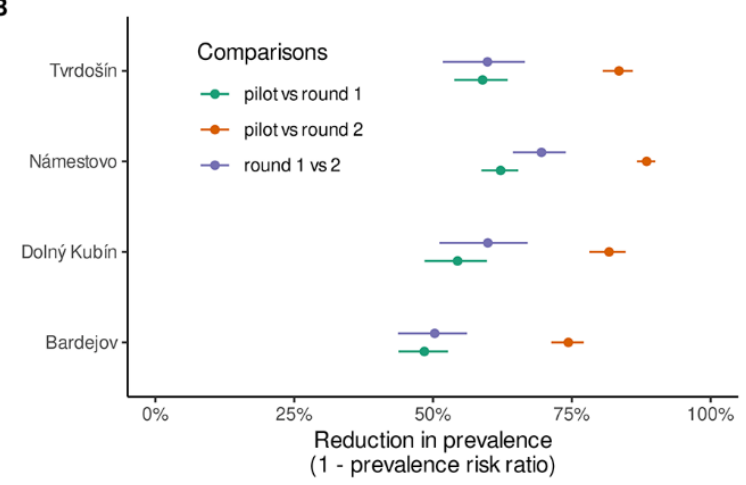

C

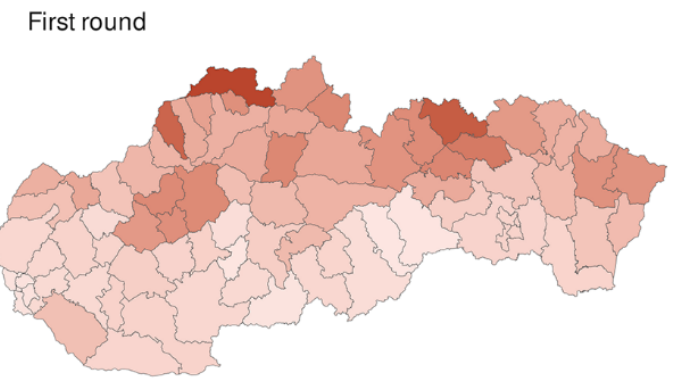

D

Second round

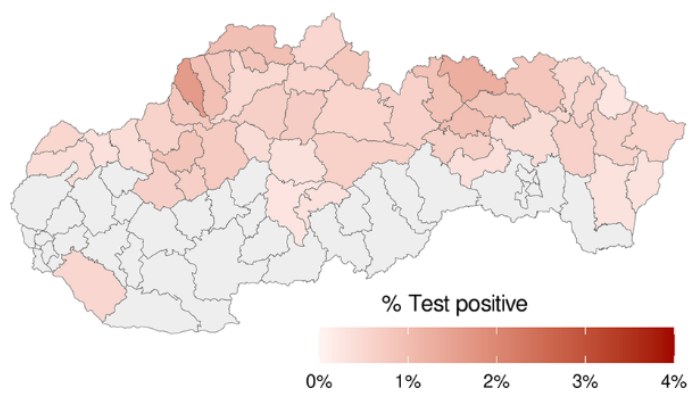

Fig. 2. The change in test positivity between mass testing campaigns. (A) Change in test positivity (1 - cPR) observed from mass testing round 1 to round 2 in the 45 counties that were eligible for both rounds of mass testing. Counties are grouped and color coded into regions. The crude pooled estimate and its $95 \%$ confidence bounds are shown as red vertical lines. How were confidence bounds derived? (B) Change in test positivity (1 cPR) observed from the pilot mass testing round to either the first (green) or the second (orange) national round and from the first to the second mass testing round (blue) in the four counties that were included in the pilot. How were confidence bounds derived? (C and D) County level test positivity in the first (C) and second (D) round of mass testing. Grey areas indicate counties that were not part of the second round because their test positivity rate was less than 7 per 1000 and hence have no estimates. 

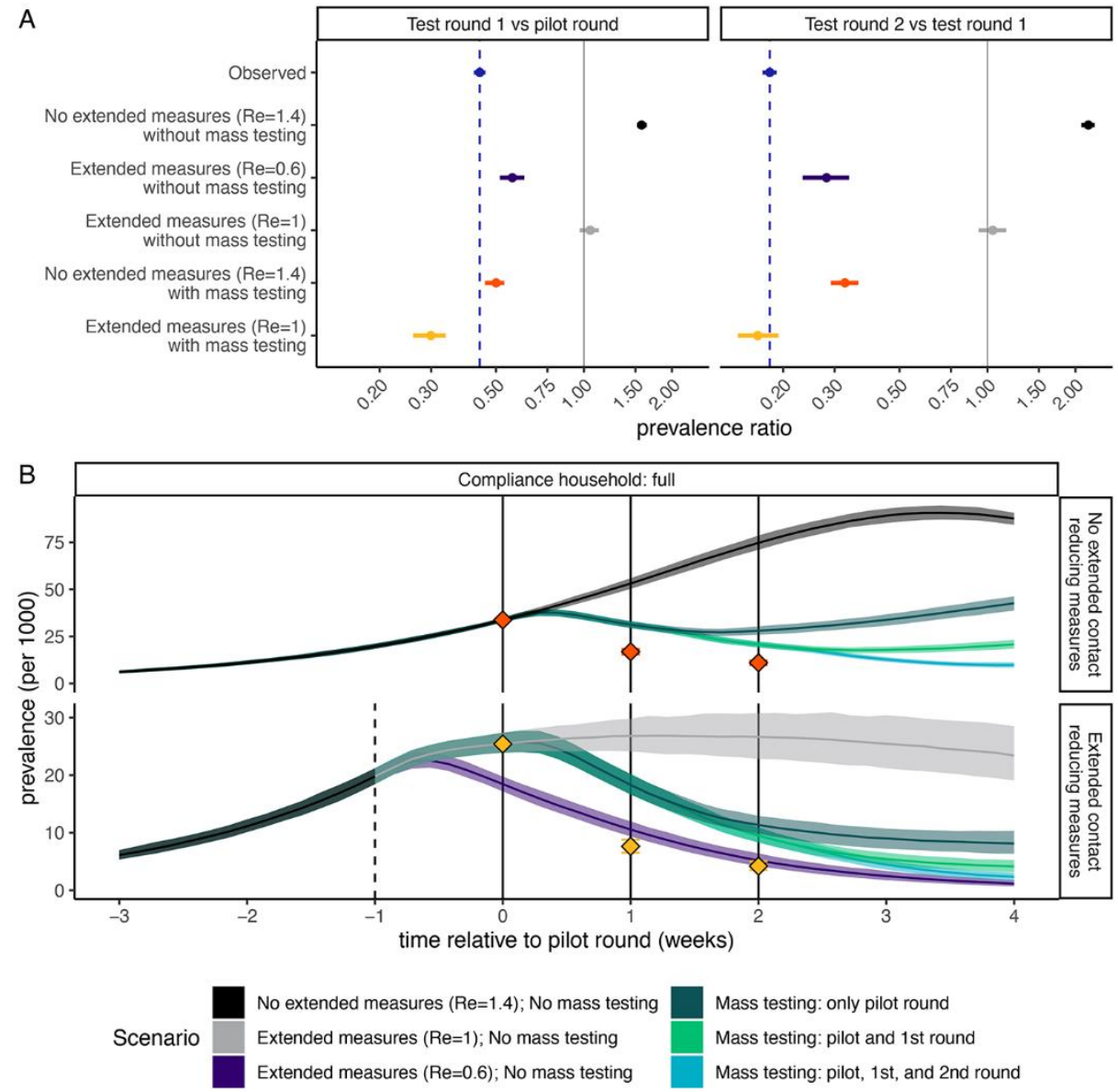

Fig. 3. Simulated relative effectiveness of the extended contact reducing measures and the mass testing. (A) The change in observed prevalence of infectious non-quarantining individuals between 10 and 65 years of age as predicted by the microsimulation model. For comparison the observed test-positivity rate is shown in blue. The facets show changes from the pilot to the first round of mass testing (left) and from the pilot to the second round of mass testing (right). Shown scenarios compare the effect of (top to bottom) no additional interventions that limit the growth rate of $\mathrm{Re}=1.4$, the extended contact reduction measures drastically reducing the growth rate to $\mathrm{Re}=0.6$ and no mass testing being conducted, the extended contact reduction measures reducing the growth rate to $\mathrm{Re}=1.0$ and no mass testing being conducted, no change in growth rate but mass testing, and the extended contact reduction measures reducing the growth rate to $R e=1$ and mass testing. In scenarios without mass testing, we compared prevalence of infectious individuals on the same days as testing occurred in scenarios with mass testing. Confidence intervals around the modeled values in each scenario are calculated as the $2.5 \%$ and $97.5 \%$ percentiles across 500 model iterations, with the point estimate representing the median. The confidence interval around the observed value is its binomial confidence interval. (B) Simulated infection incidence of alternative intervention strategies. Simulations are aligned by the date of the first mass test $(\mathrm{t}=0)$. The dashed line indicates the timing of the extended contact reducing measures and the solid lines the timing of the mass testing campaigns. Colors indicate the simulations stratified into whether no mass testing or 1, 2 or 3 testing rounds were performed and the effectiveness of the extended contact reduction measures on the growth rate. Red and yellow diamonds indicate the prevalence of infectiousness observed among the tested non-quarantining age-eligible population, corresponding to the scenarios in the top panel. 
Table 1: Overview of county specific test numbers and reductions for the 79 counties in Slovakia. R: median estimate of the reproduction number on 22 October, based on test-positive cases from syndromic surveillance up to 30 October and estimated using a renewal process model on back-calculated estimates of infection incidence. \%: proportion positive out of those attending mass testing.

\begin{tabular}{|c|c|c|c|c|c|c|c|c|c|c|c|c|}
\hline \multirow[b]{2}{*}{ County } & \multirow[b]{2}{*}{ Region } & \multicolumn{5}{|c|}{ Pilot } & \multicolumn{2}{|c|}{ Round 1} & \multicolumn{3}{|c|}{ Round 2} & \multirow[b]{2}{*}{$\%$} \\
\hline & & $\begin{array}{l}\text { Popula- } \\
\text { tion }\end{array}$ & $\mathbf{R}^{A}$ & $\begin{array}{l}\text { Attend- } \\
\text { ance }\end{array}$ & Positive & $\%$ & $\begin{array}{l}\text { Attend- } \\
\text { ance }\end{array}$ & Positive & $\%$ & $\begin{array}{l}\text { Attend- } \\
\text { ance }\end{array}$ & Positive & \\
\hline Bánovce nad Bebravou & Trenčiansky kraj & 36281.5 & 1.4 & & & & 23264 & 457 & 1.96 & 622248 & 192 & 0.86 \\
\hline Banská Bystrica & Banskobystrický kı & aj110828.5 & 1.2 & & & & 64127 & 687 & 1.07 & 766544 & 231 & 0.35 \\
\hline Banská Štiavnica & Banskobystrický kı & aj16086.0 & 0.7 & & & & 11725 & 33 & 0.28 & & & \\
\hline Bardejov & Prešovský kraj & 77771.0 & 0.7 & 48320 & 1569 & 3.25 & 544197 & 740 & 1.67 & 743983 & 366 & 0.83 \\
\hline Bratislava I & Bratislavský kraj & 44798.0 & 1.2 & & & & 29047 & 108 & 0.37 & & & \\
\hline Bratislava II & Bratislavský kraj & 108139.0 & 1.2 & & & & 80958 & 345 & 0.43 & & & \\
\hline Bratislava III & Bratislavský kraj & 61418.0 & 1.2 & & & & 49788 & 175 & 0.35 & & & \\
\hline Bratislava IV & Bratislavský kraj & 93058.0 & 1.2 & & & & 63857 & 81 & 0.13 & & & \\
\hline Bratislava V & Bratislavský kraj & 141259.0 & 1.2 & & & & 68139 & 268 & 0.35 & & & \\
\hline Brezno & Banskobystrický kr & aj61449.5 & 1.4 & & & & 37339 & 450 & 1.21 & 138515 & 242 & 0.63 \\
\hline Bytča & Žilinský kraj & 30917.0 & 1.6 & & & & 21419 & 328 & 1.5 & 320931 & 164 & 0.78 \\
\hline Čadca & Žilinský kraj & 90080.0 & 1.0 & & & & 53907 & 1736 & 3.22 & 252304 & 506 & 0.97 \\
\hline Detva & Banskobystrický kı & aj32051.0 & 1.3 & & & & 19704 & 211 & 1.07 & 723255 & 79 & 0.34 \\
\hline Dolný Kubín & Žilinský kraj & 39456.5 & 1.0 & 29347 & 916 & 3.12 & 224251 & 345 & 1.42 & 224170 & 138 & 0.57 \\
\hline Dunajská Streda & Trnavský kraj & 122358.0 & 1.3 & & & & 87329 & 840 & 0.96 & 6110083 & 577 & 0.52 \\
\hline Galanta & Trnavský kraj & 94076.0 & 1.3 & & & & 71243 & 349 & $0.4 C$ & & & \\
\hline Gelnica & Košický kraj & 31868.0 & 1.3 & & & & 18331 & 131 & 0.71 & 119087 & 72 & 0.38 \\
\hline Hlohovec & Trnavský kraj & 45012.5 & 1.4 & & & & 28892 & 171 & 0.5 & & & \\
\hline Humenné & Prešovský kraj & 61985.5 & 1.1 & & & & 32962 & 598 & 1.8 & 132750 & 197 & 0.60 \\
\hline Ilava & Trenčiansky kraj & 59187.5 & 1.4 & & & & 37604 & 442 & 1.18 & 835931 & 291 & 0.81 \\
\hline Kežmarok & Prešovský kraj & 75235.0 & 1.4 & & & & 43959 & 845 & 1.92 & 243252 & 390 & 0.90 \\
\hline Komárno & Nitriansky kraj & 101711.5 & 1.5 & & & & 61268 & 343 & 0.56 & & & \\
\hline Košice - okolie & Košický kraj & 129543.5 & 1.2 & & & & 32849 & 196 & 0.60 & & & \\
\hline Košice I & Košický kraj & 67513.0 & 1.2 & & & & 39314 & 295 & 0.75 & & & \\
\hline Košice II & Košický kraj & 82287.5 & 1.2 & & & & 11109 & 41 & 0.37 & & & \\
\hline Košice III & Košický kraj & 28748.5 & 1.2 & & & & 26992 & 135 & 0.50 & & & \\
\hline Košice IV & Košický kraj & 60126.0 & 1.2 & & & & 80426 & 487 & 0.61 & & & \\
\hline Krupina & Banskobystrický kı & aj22182.0 & 1.4 & & & & 13388 & 66 & 0.45 & & & \\
\hline Kysucké Nové Mesto & Žilinsk & 32914.0 & 1.6 & & & & 20605 & 384 & 1.86 & 620491 & 177 & 0.86 \\
\hline Levice & Nitriansky kraj & 110824.0 & 1.4 & & & & 70155 & 375 & 0.53 & & & \\
\hline Levoča & Prešovský kraj & 33702.0 & 1.0 & & & & 18344 & 373 & 2.03 & 317747 & 172 & 0.97 \\
\hline Liptovský 1 & Žilinský kraj & 72260.5 & 1.2 & & & & 47172 & 667 & 1.41 & 146827 & 267 & 0.57 \\
\hline Lučenec & Banskobystrický kl & aj73466.0 & 1.0 & & & & 40655 & 213 & 0.52 & & & \\
\hline Malacky & Bratislavský kraj & 74323.0 & 1.3 & & & & 54657 & 285 & 0.52 & & & \\
\hline Martin & Žilinský kraj & 96338.0 & 1.5 & & & & 56533 & 771 & 1.36 & 657513 & 381 & 0.66 \\
\hline Medzila & Prešovský kraj & 11841.5 & 1.1 & & & & 6980 & 91 & 1.30 & 06142 & 17 & 0.28 \\
\hline Michalovce & Košic & 110705.0 & 1.0 & & & & 58929 & 512 & 0.8 & 762790 & 211 & 0.34 \\
\hline Myjava & Trenčiansky kraj & 26356.0 & 0.9 & & & & 17753 & 249 & 1.40 & 018599 & 68 & 0.37 \\
\hline Námestovo & Žilinský kraj & 62663.5 & 0.9 & 40052 & 1910 & 4.77 & 737029 & 668 & 1.80 & 037659 & 207 & 0.55 \\
\hline Nitra & Nitriansky kraj & 161560.0 & 1.3 & & & & 99175 & 674 & 0.68 & & & \\
\hline Nové Mesto nad Váhom & nTrenčiansky kraj & 62553.5 & 1.5 & & & & 40829 & 363 & 0.85 & 946269 & 198 & 0.43 \\
\hline Nové Zámky & Nitriansky kraj & 139004.5 & 1.3 & & & & 79234 & 478 & 0.60 & & & \\
\hline Partizánske & Trenčiansky kraj & 45596.5 & 1.5 & & & & 26492 & 494 & 1.86 & 627585 & 186 & 0.67 \\
\hline Pezinok & Bratislavský kraj & 65145.0 & 1.3 & & & & 45801 & 240 & 0.52 & & & \\
\hline Piešt'any & Trnavský kraj & 62802.5 & 1.3 & & & & 40122 & 183 & 0.46 & & & \\
\hline Poltár & Banskobystrický kı & aj21471.0 & 2.0 & & & & 12455 & 71 & 0.57 & & & \\
\hline & Prešovský kraj & 104913.5 & 1.4 & & & & 59072 & 1059 & $1.7 \mathrm{C}$ & 958098 & 364 & 0.63 \\
\hline Považská Bystrica & Trenčiansky kraj & 62438.5 & 1.4 & & & & 37822 & 505 & 1.3 & 436092 & 343 & 0.95 \\
\hline
\end{tabular}




\begin{tabular}{|c|c|c|c|c|c|c|c|c|c|c|c|c|}
\hline \multirow[b]{2}{*}{ County } & \multirow[b]{2}{*}{ Region } & \multicolumn{5}{|c|}{ Pilot } & \multicolumn{2}{|l|}{ Round 1} & \multicolumn{3}{|c|}{ Round 2} & \multirow[b]{2}{*}{$\%$} \\
\hline & & $\begin{array}{l}\text { Popula- } \\
\text { tion }\end{array}$ & $\mathbf{R}_{\mathbf{a}}^{\mathrm{A}}$ & $\begin{array}{l}\text { Attend- } \\
\text { ance }\end{array}$ & Positive & $\%$ & $\begin{array}{l}\text { Attend- } \\
\text { ance }\end{array}$ & Positive & $\%$ & $\begin{array}{l}\text { Attend- } \\
\text { ance }\end{array}$ & Positive & \\
\hline Prešov & Prešovský kraj & 175609.5 & 1.0 & & & & 84781 & 724 & 0.85 & 108271 & 472 & 0.44 \\
\hline Prievidza & Trenčiansky kraj & 133979.5 & 1.3 & & & & 76457 & 1497 & 1.96 & 77170 & 576 & 0.75 \\
\hline Púchov & Trenčiansky kraj & 44309.5 & 1.3 & & & & 29455 & 782 & 2.65 & 28017 & 461 & 1.65 \\
\hline Revúca & Banskobystrický kr & aj39636.5 & 1.7 & & & & 21419 & 58 & 0.27 & & & \\
\hline Rimavská Sobota & Banskobystrický kr & aj84159.0 & 1.7 & & & & 46872 & 197 & 0.42 & & & \\
\hline Rožňava & Košický kraj & 62208.5 & 1.2 & & & & 34307 & 100 & 0.29 & & & \\
\hline Ružomberok & Žilinský kraj & 56702.0 & 1.6 & & & & 34000 & 682 & 2.01 & 33056 & 236 & 0.71 \\
\hline Sabinov & Prešovský kraj & 60518.5 & 1.4 & & & & 35366 & 804 & 2.27 & 34757 & 295 & 0.85 \\
\hline Šal'a & Nitriansky kraj & 51685.0 & 1.2 & & & & 31993 & 199 & 0.62 & & & \\
\hline Senec & Bratislavský kraj & 89832.0 & 1.4 & & & & 66052 & 314 & 0.48 & & & \\
\hline Senica & Trnavský kraj & 60446.0 & 1.2 & & & & 40675 & 384 & 0.94 & 46000 & 194 & 0.42 \\
\hline Skalica & Trnavský kraj & 47104.5 & 1.2 & & & & 29223 & 368 & 1.26 & 31200 & 168 & 0.54 \\
\hline Snina & Prešovský kraj & 36240.5 & 1.3 & & & & 19122 & 345 & 1.80 & 19396 & 111 & 0.57 \\
\hline Sobrance & Košický kraj & 22819.0 & 0.9 & & & & 12986 & 135 & 1.04 & 12966 & 43 & 0.33 \\
\hline Spišská Nová Ves & Košický kraj & 99765.0 & 1.3 & & & & 54279 & 739 & 1.36 & 53712 & 361 & 0.67 \\
\hline Stará L’ubovňa & Prešovský kraj & 53953.5 & 1.2 & & & & 28749 & 805 & 2.80 & 27234 & 354 & 1.30 \\
\hline Stropkov & Prešovský kraj & 20532.0 & 1.1 & & & & 10494 & 125 & 1.19 & 10764 & 63 & 0.59 \\
\hline Svidník & Prešovský kraj & 32564.0 & 1.1 & & & & 16631 & 220 & 1.32 & 16705 & 85 & 0.51 \\
\hline Topol'čany & Nitriansky kraj & 70131.5 & 1.4 & & & & 44627 & 748 & 1.68 & 50253 & 330 & 0.66 \\
\hline Trebišov & Košický kraj & 105353.0 & 0.9 & & & & 68503 & 400 & 0.58 & & & \\
\hline Trenčín & Trenčiansky kraj & 114523.0 & 1.2 & & & & 73424 & 832 & 1.13 & 72546 & 434 & 0.60 \\
\hline Trnava & Trnavský kraj & 132454.5 & 1.2 & & & & 92215 & 557 & 0.60 & & & \\
\hline Turčianske Teplice & Žilinský kraj & 15884.0 & 1.7 & & & & 11287 & 112 & 0.99 & 12210 & 54 & 0.44 \\
\hline Tvrdošín & Žilinský kraj & 36180.0 & 1.3 & 22250 & 1078 & 4.84 & 18541 & 369 & 1.99 & 20502 & 164 & 0.80 \\
\hline Vel'ký Krtíš & Banskobystrický kr & aj43473.0 & 1.2 & & & & 24652 & 76 & 0.31 & & & \\
\hline Vranov nad Topl'ou & Prešovský kraj & 80766.5 & 1.4 & & & & 43552 & 460 & 1.06 & 45424 & 281 & 0.62 \\
\hline Žarnovica & Banskobystrický kr & aj26152.5 & 1.4 & & & & 16272 & 105 & 0.65 & & & \\
\hline Žiar nad Hronom & Banskobystrický kr & aj46861.5 & 0.8 & & & & 26260 & 108 & 0.41 & & & \\
\hline Žilina & Žilinský kraj & 158043.0 & 1.5 & & & & 111155 & 1392 & 1.25 & 103898 & 512 & 0.49 \\
\hline Zlaté Moravce & Nitriansky kraj & 40572.5 & 0.9 & & & & 26180 & 156 & 0.60 & & & \\
\hline Zvolen & Banskobystrický kr & aj68758.5 & 1.4 & & & & 39422 & 276 & 0.70 & 47764 & 136 & 0.28 \\
\hline
\end{tabular}

